\title{
The Chattanooga Joint Library Operation: An Evaluation
}

The first four years of the association of the university and city libraries at Chattanooga are reviewed in this statement by the librarian of the university.

$T_{\text {PE IDEA for the joint Chattanooga }}^{\text {He }}$ I Public Librarý and the University of Chattanooga Library building originated with Adolph S. Ochs, publisher of the New York Times and the Chattanooga Times. Mr. Ochs, whose interest in Chattanooga never lagged in his forty years of residence in New York, was approached regarding library matters, in 1928, by the president of the university and a member of the public library board, each in ignorance of the other's appeal and at different moments. He promised each to think the request over, and the consequence was the suggestion that the joint building be erected.

It was a startling idea. There was no precedent for it, and doubtless it would never have occurred to anyone associated with either institution. There was some basis for it in the way the university (actually, it is a liberal arts college now but has had schools of law, theology, and medicine in the past) had projected itself into the cultural life of the community. The gallery of the Chattanooga Art Association is on the campus and has been for many years. Its director is a faculty member of the college, as is the director of the Chattanooga Symphony Orchestra. These are but two of several similar evidences.

The campus is located only six blocks from the center of the city's business section. There is ample parking space available, and several of the more important bus and streetcar lines pass the college. There was space on the campus for the building. Mr. Ochs pointed out these advantages, as well as the savings which could be effected in such unesthetic, but important, matters as heat, light, and janitor service.

His most pertinent arguments were different, although no less practical. There were the advantages of a joint collection, with the additional strength each would give the other. There were the opportunities for cooperative buying. Finally, he expressed his opinion that the university would more and more become the center of cultural activities in the city. This association would be one more step in that direction and the public library would gain by being a part of such a center.

The ever-active mind of Mr. Ochs went on to visualize groups joining in such a cooperative enterprise. The medical association, the garden elubs, the little theatre, music and art study groups-all these would be brought in, he believed, once the principle of cooperation was established. $\mathrm{He}$ then made the personal offer of one hundred thousand dollars to aid the project, an offer never realized because of his death before the building was constructed.

Before all the details for the joint operation could be worked out agreeably to the four contracting parties-Hamilton County, the City of Chattanooga, the public library 
board of directors, and the University of Chattanooga Board of Trustees-the financial disaster of 1929 had occurred. It did not discourage $\mathrm{Mr}$. Ochs but it threw a decided damper upon the public authorities, who feared that the bonds necessary to their share of the financial arrangements could not be sold.

It was not until a grant was made under the Public Works Administration in 1938 -three years after the death of Mr. Ochsthat the building could be erected. It was occupied by the two libraries in the spring of I940, so more than four years of joint occupancy now have passed. The time has come for at least a partial evaluation of accomplishment. The short history which has been given can form some basis for such a consideration.

The intention of the two institutions has been to move slowly in their field of cooperation. As those who have seen the plans of the building ${ }^{1}$ realize, it is so constructed that the libraries can function as separate units, each with its own staff, reading rooms, and stacks. The only necessary cooperation is that a single heating plant serves both libraries. From there, the cooperation can continue or remain, as those in charge may desire.

No one has wished, however, to hinder joint development. Constantly, it has been the intention of everyone connected with the two libraries to further as much as possible the association. This has been the greatest aid and in many ways the chief incentive to accomplishment: that, from administrative heads to newest assistants, there has been a determination to achieve the utmost from the possibilities.

It is true that finances have never been able to match the intentions. Nevertheless, much has been accomplished. First, there was established a system of immediate

${ }^{1}$ Govan, Gilbert E., and Rowell, Adelaide C. "The Chattanooga Library Building." Library Journal 66: 543-47, June I 5,194 . interlibrary loans. Under this arrangement, librarians from either library go into the stacks of the other and secure books and charge them out, thus making it possible to give almost as quick service through interlibrary loan as on direct loan to the user. This was not so necessary from the requirements of the students of the college, who hold their cards and are served by the public library as are other members of the public, as it was for patrons of the public library.

\section{Use by General Public}

Fears had been expressed in some quarters that the close juxtaposition of the two would cause the college library to be overrun by members of the public seeking specialized books and thus hinder service to the students. A rule was, therefore, established that the public would not be allowed to use the college reading rooms but could use its books, unless reserved for student use, in the reading rooms of the public library.

In order that these arrangements be completely effective, a union catalog should be prepared. The funds are not available to do this completely, but, since the two libraries were joined, an author card for each new addition by one has been placed in the cata$\log$ of the other. One immediately perceivable result has been a constantly growing increase of interlibrary loans from the college to the public library. This service has unquestionably made friends for both institutions among the public served. What its ultimate effect may be upon the reading habits and the educational development of the community will require more than four or five years to determine.

The placing of a small auditorium in the building has enabled the two institutions to institute successful joint programs and forums. Unfortunately, this auditorium for the last two years has had to be used for other purposes, but once it is again available, 
the hope is to resume its use for group meetings, for forums, and for other activities of community, public library, and college interest.

Probably the most challenging opportunity offered in this Chattanooga experiment, largely because it is an exploration of a new area, is in the field of cooperative purchasing of books and periodicals. To realize it completely, both institutions should have more funds. That remark is not intended to convey its obvious implication; what is meant is that limited funds have largely forced each institution to stay within the bounds of its primary interest, thus creating less opportunity for duplication than would otherwise be the case.

As is usual with college libraries, the funds appropriated to the university library for buying books and periodicals are allocated to departments of the university, except for a percentage retained by the librarian, to be used at his discretion to keep the collection in balance and for general and reference purchases. The major portion of the books and periodicals bought are, consequently, for specific academic purposes.

The public library, on the other hand, confines itself of necessity to general and popular reading. The institution is not unique in having to struggle along, meeting a large public demand on limited funds. Naturally, this demand is more for general than specialized reading. Thus, that situation has largely taken care of the possibility of excessive duplication in the two collections.

\section{Cooperation of Staffs}

However, there are areas where, in addition to the natural division caused by the reading desires of patrons, the staffs of the two institutions can consult and assign certain fields to one library and others to the other. As discussion of all these would necessarily entail duplication, it might be well to allow one-the reference collections-to stand as an example of the whole matter of cooperation in purchasing.

The two reference rooms are located on the same floor of the building. As on all other floors, the only means of communication between the two libraries are doors for administrative or staff use. But any user of either library may request from the assistant on duty a book or periodical in the other, and it can be secured easily and quickly. Reference catalogs have been exchanged, as have periodical catalogs, to facilitate this.

The books of one category obviously are needed in both places-for example, Webster's New International Dictionary, the Encyclopaedia Britannica, and the Dictionary of American Biography. Locations for a second group are determined largely by where the greater use is. The university library has to have certain departmental tools, such as the Mental Measurements Yearbook and Beilstein's Handbuch der Organischen Chemie, the use of which in a public library in a city of the size of Chattanooga would be infrequent. The public library has much use, on the other hand, for such volumes as Thomas' Register of American Manufacturers and the publications of Moody's Investors Service, as well as for certain biographical titles which are not so important to the college library. Included in the second group are annual publications, except for such universally necessary items as the World Almanac and the Blue Book of Southern Progress. A third category is more limited, and so far has been confined to tools used by the librarians. The sort of division here described has also worked very effectively in the buying of periodicals.

There are other areas in which the cooperation between the two libraries has been very effective. One was foreseen, in that the building is so planned that the two cataloging rooms were placed side by side. The 
two libraries have both undertaken recataloging projects since moving into the new building. The catalogers have consequently had the assistance of an interchange of advice and experience, with benefit to both parties. Difficult problems of classification or filing are the more easily solved by bringing all minds to work upon them.

\section{Other Libraries}

So far, this discussion has been about rather obvious things. It was to be expected that they would be attempted and accomplished, completely or in some degree. Once the principle of cooperation was established, as Mr. Ochs foresaw, there might be unexpected efforts to join the project. It is in these that probably the most interesting developments at Chattanooga have occurred.

First came a proposal from the doctors. The local medical association had established a small library some years back in a basement room of the Medical Arts Building. No particular attention was given it, but it furnished enough assistance to the members for them to wish to expand it. The new library offered the opportunity. When it was suggested to them that they have their own room and adjoining stack space in the building, they were not only receptive but enthusiastic. They raised money for the purchase of books and journals. The university library placed with these such related periodicals and books as it had. The public library furnished service. There is now a useful and growing collection of medical reference material available to the public as well as to the doctors. $^{2}$ It should not be lost sight of, also, that the university students have at their disposal all these facilities as members of the public served by the library.

In any sphere of library cooperation in-

${ }^{2}$ This experience has been described by Mildred Crowe, medical librarian, Chattanooga Public Library, in "A Medical Society Library in a Public Library." Bulletin of the Medical Library Association 32:221-29, April r944. It has been offered as a possible guide for similar efforts elsewhere. cluding a public library, ways should be sought to create greater interest from the side of the public schools. One of the immediately obvious approaches is in the collecting of educational films. This, in most localities, is virtually virgin territory. The schools use their funds allotted for this purpose to rent, seldom to purchase, films. When it was suggested that a portion of these funds be pooled annually for the purchase of films, which would be stored and administratively cared for by the library, it had an immediate appeal. Unfortunately, the war has created conditions which have worked against this project. Some of the more enthusiastic members of the committee appointed to carry on the film library have, themselves, left for military service. The nucleus has been started, though, and once the war is over, it is hoped that a revival of the complete program will occur.

One interesting development has been the building of a journalism library. The executive offices of the Southern Newspaper Publishers' Association are in Chattanooga. The executive secretary was immediately interested in the suggestion that a collection be established here which would include books on all technical phases of journalism, as well as anniversary issues of the member papers (which extend from Virginia through Texas), and books-on whatever subject-by those connected with member papers. A result is that this is more than a collection of books on journalism. It embraces good local history collections on many communities, as anniversary editions are largely composed of that sort of material.

The Tennessee Valley Authority has been brought into the library's operation in several ways. There have been grants-inaid to the public library because of its service to local groups connected with the authority. But the most valuable thing the authority has yet done is to deposit with the university library, for the use of serious research schol- 
ars, certain of its work studies for the sociological and economic monographs published by or for the authority.

For years the Engineers' Club of Chattanooga has appropriated money to purchase periodicals in its fields of interest for the public library. Thus, its cooperative interest is of long standing. It has only been within the last few months, though, that it has been able to secure the funds to do what it has wished, that is, to equip a room and to purchase necessary reference volumes for it. These quarters are now in the process of organization, and again the college will participate by placing in the room those of its holdings which will both strengthen and be strengthened by the rest of the collection.

Before closing this discussion, it should be pointed out that some of the academic collections have proved particularly important for public use in the present emergency. It had not been foreseen that a demand would be created by the war for books in the fields of foreign languages, mathematics, and the other natural sciences. These have proved valuable for many public library patrons. Other circumstances may develop which will show additional values not foreseen in planning for joint library operation.

These are the more striking of the developments in this enterprise. In themselves, they convey some idea of the success which has attended the first four years of joint effort. There remain two other sources from which opinions may be secured to aid in evaluation. First is that of users. A group of citizens were asked their opinions, as were members of the faculty and student body of the college. All had praise for the operation and the possibilities of further development. Only one objection was advanced: some of the citizens think the distance from downtown a little too great and more than usually irksome in these days of gasoline rationing. The fact that the additional distance from the old location of the public library is but four blocks probably will cause that to appear inconsequential to residents of larger communities. The public library, however, has taken recognition of the objection by establishing a downtown branch. This is open from twelve to two and has a changing deposit of books. Other titles which are requested are taken from the main collections.

The staffs of the two libraries also have mentioned the location as their major objection, except for certain practical difficulties which could not be anticipated at the start and which call for minor changes in plan. Without exception, though, they have expressed their pleasure over what has been accomplished and with the possibilities which lie ahead.

The chief interest for college librarians will be in those areas affecting the college, its faculty, and its students. Several results are immediately apparent: the increase of the available book and periodical collections to include the holdings of the public library ; the fact that the public library reading rooms offer additional space; the increase of trained help by public library assistants in securing materials. There are similar advantages for the public from the university collections and staff. Whether this particular experiment offers a model for other institutions and communities depends largely upon local conditions. If the college campus, as is the instance here in Chattanooga, is located sufficiently close to the center of the community, it would appear practical to consider it.

At any rate, we of Chattanooga have demonstrated to our own satisfaction and that of our clientele, that there is no barrier to a close cooperative effort between a public library and the library of a liberal arts college, if the members of the two staffs have the vision and the determination to make it a success. 